\title{
Synthesis and Secretion of Alpha-2-Macroglobulin by Cultured Adherent Lung Cells
}

\author{
COMPARISON WITH CELL STRAINS DERIVED FROM OTHER TISSUES
}

\author{
Deane F. Mosher, Olli Saksela, and Antti Vaheri, Department of Virology, \\ University of Helsinki, SF-00290 Helsinki 29, Finland
}

\begin{abstract}
A в S T R A C T We studied the synthesis and secretion of alpha-2-macroglobulin by cultures of human adherent cells. Much more alpha-2-macroglobulin (measured by radioimmunoassay) accumulated in media of established strains of adherent cells derived from embryonic lung than in media of established strains derived from adult skin or rheumatoid synovium. Alpha2-macroglobulin accumulated in media of primary cultures of adherent cells from a variety of embryonic tissues. However, the amount of alpha-2-macroglobulin accumulating in media of subsequent passage of these cells declined for all strains except those derived from lung. Immunodiffusion and double-antibody immunoprecipitation studies of cell extracts and media after incubation of cells with $\mathbf{L}-\left[{ }^{35} \mathrm{~S}\right]$ methionine supported the radioimmunoassay finding that adherent cells from lung synthesized and secreted more alpha-2-macroglobulin than adherent cells from skin. Intracellular alpha-2-macroglobulin could not be detected by radioimmunoassay or visualized by immunofluorescent microscopy, suggesting that synthesized alpha-2-macroglobulin is rapidly secreted. Plasminogen-rich fibrin clots were lysed in culture media of adherent cells from embryonic lung and, to a lesser extent, heart. Adherent cells from other tissues, which produced less alpha-2-macroglobulin, did not lyse fibrin clots. However, all cultures of adherent cells contained pericellular fibronectin, a large, external, transformation-sensitive glycoprotein known to be cleaved by plasmin. We speculate that production of alpha-2-macroglobulin may be a means for protease-secreting normal cells to preserve cell surface integrity and that alpha-2-macroglobulin synthesized locally in lung may protect lung tissues from a variety of proteases.
\end{abstract}

Dr. Mosher's present address is Department of Medicine, University of Wisconsin, Madison, Wisconsin 53706.

Received for publication 28 March 1977 and in revised form 8 July 1977.

\section{INTRODUCTION}

Alpha-2-macroglobulin is a major protease inhibitor of human plasma. It is unique among the circulating protease inhibitors in respect to: $(a)$ its large size (6.0-8.0 $\times 10^{5}$ daltons); $(b)$ the wide spectrum of proteases it inhibits; and $(c)$ the manner in which it inhibits proteolysis while protecting enzymic activity towards small substrates ( 1 and references therein). We have reported evidence indicating that WI-38 fibroblastic cells, derived from human embryonic lung, synthesize and secrete alpha-2-macroglobulin (2). Inasmuch as proteases have been implicated in a number of the physiological and pathological functions of cultured cells and of tissues (3), including lung (4), we developed more sensitive methods to analyze synthesis and secretion of alpha-2-macroglobulin in cell culture experiments. In this paper, we describe experiments showing that adherent cells derived from lung produce more alpha-2-macroglobulin than cells grown from other embryonic and adult tissues.

\section{METHODS}

Materials. Reagents were purchased from the following suppliers: $\mathrm{Na}^{125} \mathrm{I}$, carrier-free, and $\mathrm{L}-\left[{ }^{35} \mathrm{~S}\right]$ methionine (380 $\mathrm{Ci} / \mathrm{mmol}$ ) (The Radio Chemical Centre, Amersham, England); rabbit anti-human alpha-2-macroglobulin (Behring-Werke, Marburg, West Germany); Sephadex G-25, Sepharose 4B, and dextran sulfate (Pharmacia Fine Chemicals Inc., Uppsala, Sweden); and DEAE-cellulose (DE-52), Whatman Chemicals, Div. W. \& R. Balston, Maidstone, England. Human plasma fibronectin $(5)^{1}$ and rabbit antifibronectin antisera were prepared as described previously (6).

\footnotetext{
${ }^{1}$ Fibronectin (5) refers to a polymorphic glycoprotein present in blood (alternatively called cold-insoluble globulin), blood vessel walls, and basement membranes. It is a major protein synthesized by cultured fibroblasts. It is commonly missing from the surfaces of malignantly transformed fibroblastic cells. When studied in cell culture, it has been given a number of names, including large external transformationsensitive (LETS) protein and cell surface protein (CSP).
} 
Purification of alpha-2-macroglobulin. Alpha-2-macroglobulin was purified from human plasma by a modification of the procedure described by Roberts et al. (7). Blood from a donor of haptoglobin type 1-1 (whose haptoglobin is known not to form large aggregates) was mixed with $1 / 20$ th vol of 200 mm EDTA, 1 M 6-aminohexanoic acid. Plasma was collected by two centrifugations at $4^{\circ} \mathrm{C}$, the first at $1500 \mathrm{~g}$ for $20 \mathrm{~min}$ in a swinging bucket rotor and the second at $5000 \mathrm{~g}$ for $20 \mathrm{~min}$ in a fixed angle rotor. Lipoproteins were precipitated by addition of $1 / 5$ th vol of $1 \mathrm{M}$ manganese chloride and 1/17th vol of $10 \%$ dextran sulfate. The precipitate was removed by centrifugation, and the supernate was dialyzed against two changes (100 vol each) of $10 \mathrm{mM}$ sodium acetate, $\mathrm{pH}$ 5.2. The precipitate forming during dialysis was removed by centrifugation. The supernate was made $0.1 \mathrm{M}$ in sodium chloride and $4 \mathrm{mM}$ in sodium phosphate, $\mathrm{pH} 7.8$, by adding $1 / 1$ oth vol of a concentrated salt solution. Saturated ammonium sulfate, $1 / 2 \mathrm{vol}$, was then added with stirring. The resulting precipitate was removed by centrifugation. An additional $1 / 2$ vol of saturated ammonium sulfate was added with stirring, and the precipitate was collected by centrifugation. The precipitate was dissolved in phosphate-buffered saline (PBS) ${ }^{2}(1 / 6$ th the original plasma volume) and chromatographed on a $5 \times 85-\mathrm{cm}$ column of Sepharose $4 \mathrm{~B}$, equilibrated, and eluted at $4^{\circ} \mathrm{C}$ with PBS. Fractions containing alpha-2-macroglobulin were identified by Laurell's electroimmunoassay (8) and were confined to the shaded peak of protein eluting from the column (Fig. 1). Fractions from this peak were pooled as indicated and analyzed by polyacrylamide gel electrophoresis in sodium dodecyl sulfate after reduction (2). There was a prominent polypeptide of $1.6 \times 10^{5}$ daltons, a minor polypeptide of 1.1 $\times 10^{5}$ daltons, and several trace polypeptides of lower molecular weight (7). The pooled fractions were dialyzed against

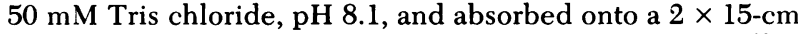
column of DEAE-cellulose equilibrated with the same buffer. The protein eluted from the column as a sharp peak when the column was developed with a $0-0.3 \mathrm{M}$ sodium chloride linear gradient (total volume of $200 \mathrm{ml}$ ). The protein was dialyzed against $\mathrm{PBS}$, frozen in dry ice-acetone, and stored in portions at $-70^{\circ} \mathrm{C}$ until used. The protein formed a single precipitation arc when analyzed by immunoelectrophoresis against anti-human serum. However, the same heterogeneity as described above was noted when the sample was analyzed by polyacrylamide gel electrophoresis in sodium dodecyl sulfate.

Radioimmunoassays. Purified alpha-2-macroglobulin was iodinated with a minimal concentration of chloramine-T as described by Krohn et al. (9). The reaction mixture contained $200 \mu \mathrm{l}$ of protein solution ( $3 \mathrm{mg} / \mathrm{ml}$ in PBS), $10 \mu \mathrm{l}$ of carrierfree $\mathrm{Na}^{125} \mathrm{I}(1 \mathrm{mCi}$ ), and $25 \mu \mathrm{l}$ of $0.7 \mathrm{mM}$ chloramine $\mathrm{T}$ freshly dissolved in $0.4 \mathrm{M}$ sodium phosphate, $\mathrm{pH}$ 7.8. Immediately after addition of chloramine $\mathrm{T}$, the reaction mixture was chromatographed on Sephadex G-25. Void volume fractions were pooled and diluted with PBS containing bovine serum albumin $(1 \mathrm{mg} / \mathrm{ml})$. Approximately 0.25 atom of ${ }^{125} \mathrm{I}$ was incorporated per $1.6 \times 10^{5}$-dalton subunit. The labeled protein migrated in sodium dodecyl sulfate-containing polyacrylamide gels at the $1.6 \times 10^{5}$-(analyzed after reduction) or $>3.0 \times 10^{5}$-(analyzed without prior reduction) dalton positions (Fig. 2). Anti-alpha-2-macroglobulin precipitated $89 \%$ of the labeled protein in a double-antibody precipitation.

Commercial rabbit anti-human alpha-2-macroglobulin antiserum was adsorbed with lyophilized fetal calf serum, 40 $\mathrm{mg} / \mathrm{ml}$. The adsorption removed all antibodies to bovine alpha-2-macroglobulin as judged by double immunodiffusion. For the double-antibody radioimmunoassay, $100 \mu \mathrm{l}$ of a $1: 10^{4}$

${ }^{2}$ Abbreviations used in this paper: PBS, phosphatebuffered saline; and BMED, Eagle's basal medium (diploid).

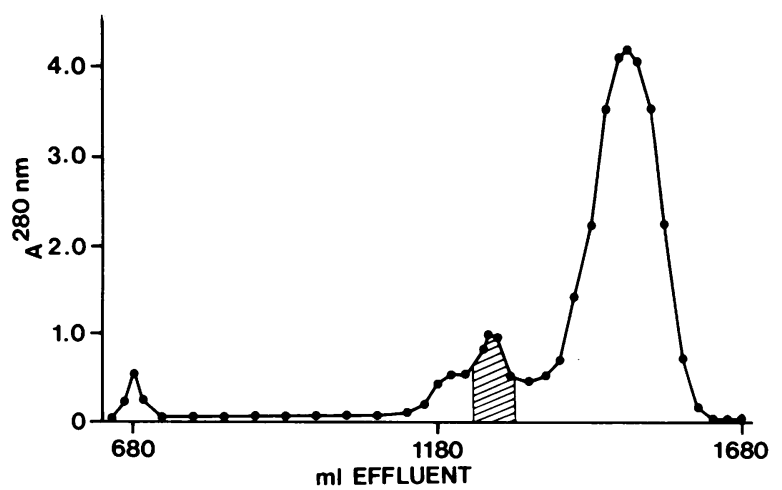

Figure 1 Chromatography of $33-50 \%$ saturated ammonium sulfate fraction on Sepharose $4 B$. The proteins, in $20 \mathrm{ml}$ of PBS, were applied to a $5 \times 85-\mathrm{cm}$ column of Sepharose $4 \mathrm{~B}$, equilibrated and developed with PBS. The shaded volume of the effluent contained alpha-2-macroglobulin.

dilution of adsorbed antiserum (sufficient to precipitate $50-60 \%$ of labeled alpha-2-macroglobulin in the absence of unlabeled alpha-2-macroglobulin), $1000 \mu \mathrm{l}$ of unknown, $100 \mu$ l of iodinated alpha-2-macroglobulin $\left(4-5 \times 10^{3} \mathrm{cpm}\right)$,

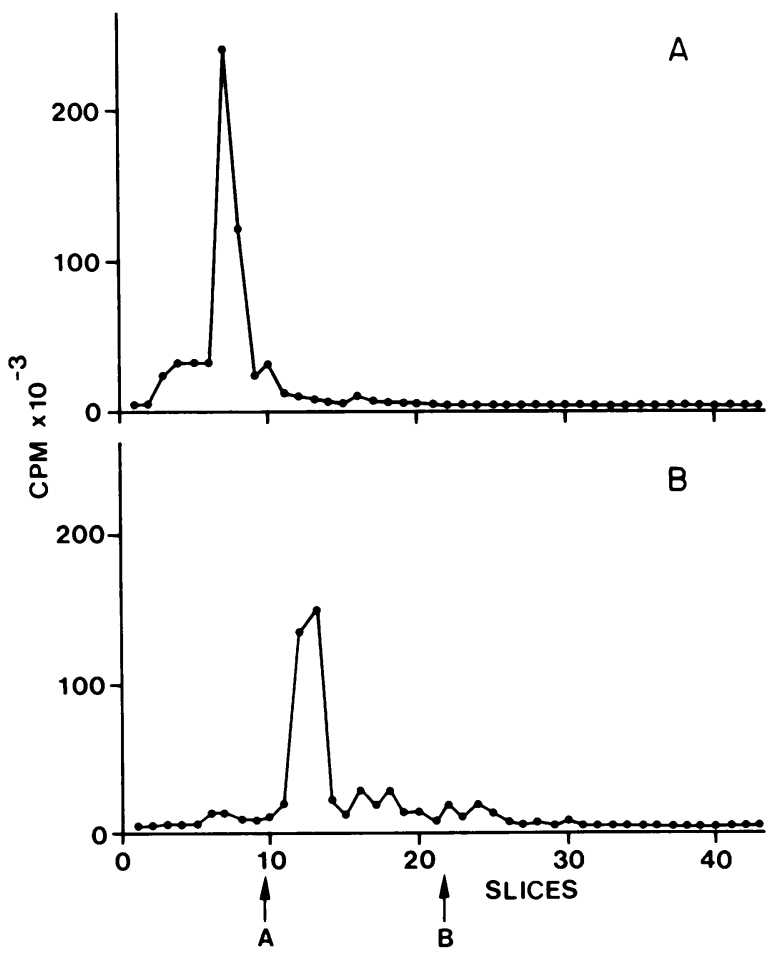

FIGURE 2 Electrophoresis of ${ }^{125} \mathrm{I}$-alpha-2-macroglobulin. Labeled alpha-2-macroglobulin was denatured in $1 \%$ sodium dodecyl sulfate with (A) or without (B) 1\% 2-mercaptoethanol and analyzed on $80-\mathrm{mm}$ cylindrical $5 \%$ polyacrylamide gels. At the completion of electrophoresis, the gels were sliced into 2 -mm disks, and radioactivity (counts per minute) was measured in a gamma counter. Arrows point to the positions where labeled plasma fibronectin, $2.0 \times 10^{5}$ daltons (A) and phosphorylase $a, 9.3 \times 10^{4}$ daltons (B) migrated. 
and $10 \mu \mathrm{l}$ of normal rabbit serum were incubated for $16 \mathrm{~h}$ at $22^{\circ} \mathrm{C}$. $150 \mu \mathrm{l}$ of sheep anti-rabbit gamma globulin was added, and the incubation was continued for an additional hour. After centrifugation at $1000 \mathrm{~g}$ for $10 \mathrm{~min}$, the supernate was drawn off, and the radioactivity in the immunoprecipitate was analyzed in an LKB-Wallac gamma counter (LKB Produkter, Stockholm). Dilutions of serum from a normal adult male served as standards. The alpha-2-macroglobulin concentration of the serum was determined by Laurell's electroimmunoassay (8) against a primary standard of purified alpha-2-macroglobulin; the $A_{280}^{1} \mathrm{mg} / \mathrm{ml}$ of the purified protein was assumed to be 1.0. When assaying cell extracts, human serum was diluted in $8 \mathrm{M}$ urea, $1.0 \%$ Triton (Rohm \& Haas Co., Philadelphia) (see below) and then diluted at least 20 -fold further to serve as a standard for 20 -fold diluted cell extracts.

Fibronectin was assayed by a similar double-antibody radioimmunoassay. ${ }^{3}$ Protein was quantitated by the method of Lowry et al. (10).

Cell culture. Cells were grown on plastic petri dishes at $37^{\circ} \mathrm{C}$ in Eagle's basal medium (BMED) supplemented with $10 \%$ fetal calf serum, penicillin $(100 \mathrm{U} / \mathrm{ml})$, and streptomycin $(50 \mu \mathrm{g} / \mathrm{ml})$. Subcultures were made at 3-6-day intervals in a 1:2 ratio. Stock cultures were tested for mycoplasma by staining for cytoplasmic DNA (11) with consistently negative results. Cultures were examined daily by light microscopy.

Primary cultures were derived from 12-16-wk human embryonic tissues obtained at surgery, Department of Obstetrics and Gynecology, University of Helsinki Central Hospital. Approximately $1 \mathrm{~g}$ was minced, rinsed once with Tris-buffered saline containing $5 \mathrm{mM}$ glucose, and stirred for $5 \mathrm{~min}$ at $22^{\circ}$ in $20 \mathrm{vol}$ of $0.25 \%$ tryspin dissolved in the same buffer. Suspended cells were collected by decantation. The trypsinization procedure was repeated twice. The cells were pooled, sedimented by centrifugation ( $200 \mathrm{~g}$ for $10 \mathrm{~min}$ ), resuspended in $10 \mathrm{ml}$ of growth medium, and seeded onto two $20-\mathrm{cm}^{2}$ petri dishes. After 1 day in culture, nonadherent cells were decanted, and fresh medium was placed over adherent cells. The cells grew to confluency in about 3 days and were subcultured as described above for established cell strains.

A number of other human cell strains were tested, including WI-38 embryonic lung cells (12), MRC-5 embryonic lung cells (13), three locally-established strains of adult forearm skin fibroblasts (E. S., E. R., and J. K. O.), and four strains derived from rheumatoid synovium (K. E., T. O., J. U., and K. A.) by Prof. P. Halonen, University of Turku.

Before radioimmunoassay, culture fluids were clarified by centrifugation at $200 \mathrm{~g}$ for $10 \mathrm{~min}$. The cells were washed three times with PBS and extracted with a solution containing $8 \mathrm{M}$ urea, $1.0 \%$ Triton $X-100,0.02 \%$ sodium azide, and $2 \mathrm{mM}$ phenylmethyl sulfonyl fluoride.

Immunoprecipitation of proteins labeled with ${ }^{35} \mathrm{~S}-$ methionine. Growth medium was removed from 3-day-old cultures, and the cultures were incubated at $37^{\circ} \mathrm{C}$ for $48 \mathrm{~h}$ in methionine-free BMED containing $0.05 \%$ bovine serum albumin and $10 \mu \mathrm{Ci} / \mathrm{ml}$ of $\mathrm{L}_{-}\left[{ }^{35} \mathrm{~S}\right]$ methionine. At the end of the incubation, the medium was mixed with $1 / 20$ th volume of human serum, and the labeled proteins were precipitated with $\mathbf{5 0 \%}$ saturated ammonium sulfate and analyzed by double immunodiffusion and autoradiography as previously described (2).

Radiolabeled alpha-2-macroglobulin and fibronectin were also precipitated from medium and cell extracts by a doubleantibody technique. Confluent cultures in $20-\mathrm{cm}^{2}$ petri dishes were washed with methionine-free BMED and incubated for

\footnotetext{
${ }^{3}$ Mosher, D. F., and A. Vaheri. 1977. Thrombin stimulates production and release of the major surface-associated glycoprotein (fibronectin) in cultured human fibroblasts. Manuscript in preparation.
}

$30 \mathrm{~min}$ before adding $\mathrm{L}-\left[{ }^{35} \mathrm{~S}\right]$ methionine $(10 \mu \mathrm{Ci} / \mathrm{ml})$ in methionine-free BMED. After an additional 4-h incubation, medium was collected, and the cells were washed and extracted with $10 \mathrm{mM}$ Tris chloride, $\mathrm{pH} 8.0$, containing $0.15 \mathrm{M}$ sodium chloride, $0.5 \%$ deoxycholate, $1 \mathrm{mM}$ phenylmethyl sulfonyl fluoride, and bovine pancreatic trypsin inhibitor (100 units $/ \mathrm{ml})$. Insoluble material in medium and cell extracts was removed by centrifugation at $15000 \mathrm{~g}$ for $60 \mathrm{~min}$ at $4^{\circ} \mathrm{C} .15 \mu \mathrm{l}$ rabbit antisera to fibronectin or alpha-2-macroglobulin or normal rabbit serum were added to $500 \mu \mathrm{l}$ of cell extract or $1000 \mu \mathrm{l}$ of medium. After incubation at $22^{\circ} \mathrm{C}$ for $2 \mathrm{~h}$ on a to-and-fro shaker, the antigen-antibody complex was precipitated by adding 300 $\mu \mathrm{l}$ of sheep anti-rabbit gamma globulin and $300 \mu \mathrm{l}$ of the Trisbuffered saline containing $2 \mathrm{mM}$ phenylmethyl sulfonyl fluoride, pancreatic trypsin inhibitor $(200$ units $/ \mathrm{ml})$, and $1.0 \%$ deoxycholate. After incubation for $12 \mathrm{~h}$ at $4^{\circ} \mathrm{C}$, the immunoprecipitate was collected by centrifugation at $3000 \mathrm{~g}$ for $30 \mathrm{~min}$. The immunoprecipitate was suspended thrice in Tris-buffered saline containing $0.5 \%$ deoxycholate and the protease inhibitors and once in water; after each wash, the immunoprecipitate was collected by centrifugation. The final precipitate was dissolved in $500 \mu \mathrm{l}$ of $4 \%$ sodium dodecyl sulfate, $10 \%$ 2-mercaptoethanol buffered to pH 6.8 with Tris-chloride.

Radiolabeled polypeptides were analyzed by discontinuous polyacrylamide slab-gel electrophoresis in sodium dodecyl sulfate (14) followed by scintillation autoradiography (15). Size standards included plasma fibronectin, $2.0 \times 10^{5}$ daltons; alpha-2-macroglobulin, $1.6 \times 10^{5}$ daltons; phosphorylase $a$, $9.3 \times 10^{4}$ daltons; bovine serum albumin, $6.8 \times 10^{4}$ daltons; and ovalbumin, $4.3 \times 10^{4}$ daltons, all labeled with $\left[{ }^{14} \mathrm{C}\right]$ formaldehyde by the method of Rice and Means (16).

Immunofluorescence. Coverslip cultures of cells grown in fetal calf serum were fixed with formaldehyde (3.5\% in PBS, $\left.20 \mathrm{~min}, 20^{\circ} \mathrm{C}\right)$ and acetone $\left(20 \mathrm{~min},-20^{\circ} \mathrm{C}\right)$ and stained with rabbit anti-human alpha-2-macroglobulin (previously adsorbed with fetal calf serum) and fluoresceinated sheep anti-rabbit IgG. As a negative control, normal rabbit serum was substituted for rabbit anti-alpha-2-macroglobulin. Fibronectin was detected by a similar technique. ${ }^{3}$

Clot lysis. Growth medium of confluent cultures was replaced with BMED and 1/10 vol of human plasma; the original anticoagulant, $10 \mathrm{mM}$ EDTA, was removed by prior dialysis of plasma against $P B S$ containing $0.1 \mathrm{mM}$ EDTA. A fine clot formed in the culture dish within 5-10 min. After incubation for $18 \mathrm{~h}$ at $37^{\circ} \mathrm{C}$, the dish was observed for complete clot lysis, partial clot lysis (fragments of clot remaining), or no clot lysis (clot intact).

\section{RESULTS}

Characteristics of radioimmunoassay. Conditioned media of MRC- 5 fibroblasts, derived from human embryonic lung, inhibited binding of radioiodinated human alpha-2-macroglobulin to rabbit antihuman alpha-2-macroglobulin (Fig. 3). The inhibition curves obtained by diluting conditioned media were similar in shape to that obtained by diluting human serum. BMED supplemented with $10 \%$ fetal calf serum did not inhibit binding once the rabbit anti-human alpha-2-macroglobulin was adsorbed with lyophilized fetal calf serum. Inasmuch as WI-38 fibroblasts derived from human embryonic lung have previously been shown by electroimmunoassay and functional assays to secrete alpha-2-macroglobulin (2), we attribute inhibi- 


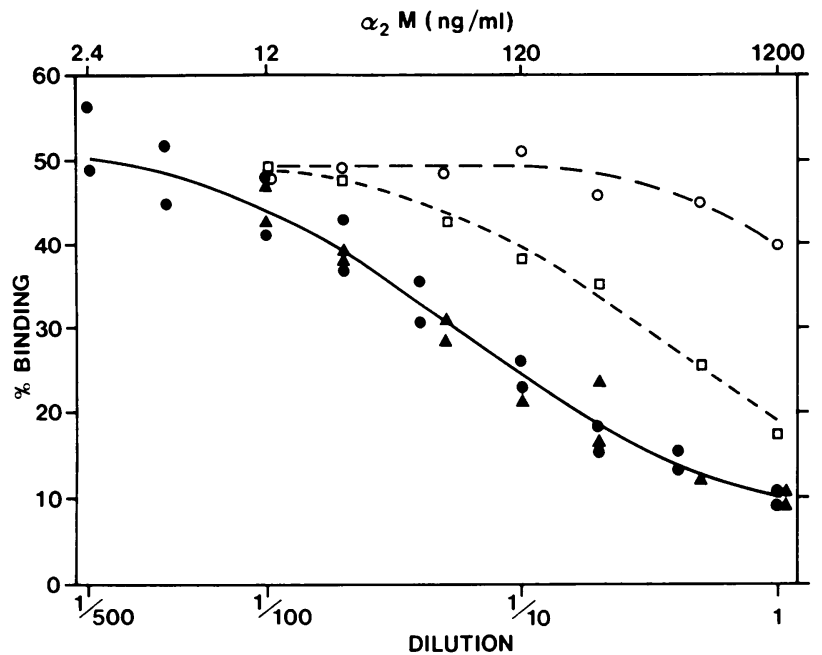

FIgURE 3 Inhibition of binding of ${ }^{125}$ I-alpha-2-macroglobulin to anti-alpha-2-macroglobulin. Serial dilutions of the following samples were tested in the radioimmunoassay: human serum previously diluted to a concentration of $1200 \mu \mathrm{g} / \mathrm{ml}$ $(\bullet)$; and conditioned medium from MRC-5 cells $(\boldsymbol{\Delta})$. Also shown are binding-inhibition curves obtained with media containing: little alpha-2-macroglobulin, HE-4 skin, primary $(\bigcirc)$; and intermediate amounts of alpha-2-macroglobulin, HE-4 lung, primary ( $\square$ ). See tables I and II. The concentrations of alpha-2-macroglobulin in the dilutions of human serum are shown at the top of the graph.

tion of binding by conditioned media to alpha-2-macroglobulin. Thus, the radioimmunoassay measured between 5 and $500 \mathrm{ng} / \mathrm{ml}$ alpha-2-macroglobulin.

TABLE I

Accumulation of Alpha-2-Macroglobulin in Media of Established Cell Strains

\begin{tabular}{lcc}
\hline \multicolumn{1}{c}{ Cell strain } & Days in culture & Alpha-2-macroglobulin \\
\hline & & $n g / m l$ \\
Adult skin & 4 & 17,16 \\
E. S. & 3 & 3 \\
E. R. & 3 & 11,16 \\
J. K. O. & & \\
Rheumatoid synovium & 4 & 7,9 \\
K. A. & 4 & $5,6,33$ \\
K. E. & 4 & $5,5,13$ \\
J. U. & 4 & 5,5 \\
T. O. & 3 & $650,550,220,200$ \\
Embryonic lung & 3 & 370,800 \\
WI-38 & 4 & $130,135,1,000,900$ \\
WI-38 & 3 & \\
MRC-5 &
\end{tabular}

The cells, all between passages nine and 20, were subcultured in BMED containing $10 \%$ fetal calf serum. Alpha-2macroglobulin concentration was determined 3 or 4 days later. All cultures were confluent at the times the media were harvested. Values represent averages of duplicate analyses of media from individual cultures.
Accumulation of alpha-2-macroglobulin in media from different cell strains. Media of established fibroblastic strains derived from human embryonic lung contained more alpha-2-macroglobulin than media of strains from adult skin or rheumatoid synovium (Table I). These differences were present at all times after subculture (Fig. 4). Alpha-2-macroglobulin was measured in media of primary, secondary, and tertiary passages of cultures derived from different embryonic tissues (Table II). More alpha-2-macroglobulin accumulated in media of primary cultures from skin, heart, kidney, and chest wall than in media of secondary and tertiary cultures from these tissues. In contrast, the amounts of alpha-2-macroglobulin accumulating in the media of the subsequent passages of lung cells from HE-4 and HE- 6 were similar to the amounts in media of the primary lung cells. As with the established strains, the differences among the embryonic strains persisted for up to 6 days after subculture. There was considerable variation in the quantities of alpha-2-macroglobulin found, both from embryo to embryo and passage to pas-
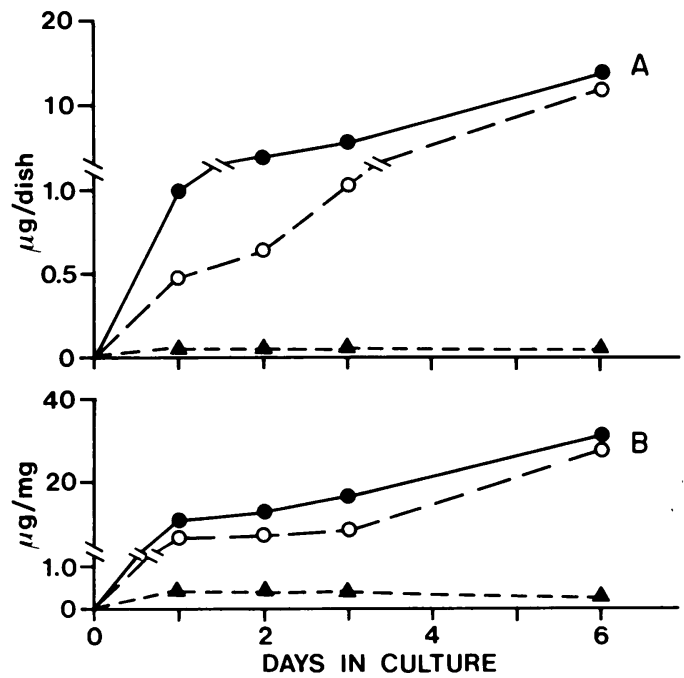

FIGURE 4 Accumulation of alpha-2-macroglobulin in medium of established cell strains. WI-38 (O) and MRC-5 (O) embryonic lung fibroblasts and J. K. O. ( $\Delta$ ) adult skin fibroblasts, in the 18th to 22 nd passages, were subcultured (1:2 split) in $20-\mathrm{cm}^{2}$ petri dishes containing $5 \mathrm{ml}$ of growth medium. At the indicated times, the incubation was terminated, and the alpha2 -macroglobulin $\left(\alpha_{2} \mathbf{M}\right)$ concentration of the medium and the protein content of the cell layer were determined. Alpha-2macroglobulin concentration is expressed as microgram/culture (A) and microgram/milligram cell protein (B). The WI-38 cells became confluent on day 3 when there was $250 \mu \mathrm{g}$ of protein in the cell layer; the MRC-5 cells became confluent on days $2-3$ when there was $325 \mu$ g of protein in the cell layer; and the J. K. O. Cells became confluent of days $2-3$ when there was $200 \mu \mathrm{g}$ of protein in the cell layer. The skin fibroblasts formed a tightly-packed monolayer with a parallel, polar orientation. The lung fibroblasts were less parallel and more refractile, and there were swirls of cells which overgrew underlying cells to form oligolayers. 
TABLE II

Accumulation of Alpha-2-Macroglobulin in Media of Embryonic Cell Strains

\begin{tabular}{|c|c|c|c|c|c|}
\hline \multirow[b]{2}{*}{ Cell strain } & \multicolumn{5}{|c|}{ Passage } \\
\hline & 1 & 2 & 3 & 4 & 5 \\
\hline & \multicolumn{5}{|c|}{$\mu g / m l$ alpha-2-macroglobulin } \\
\hline HE-4 & (4 days) & (3 days) & (4 days) & & \\
\hline Skin & 13.5 & 6.1 & 18.3 & - & - \\
\hline Lung & 260 & 27.8 & 157 & - & - \\
\hline Heart & 90 & 17.0 & 25 & - & - \\
\hline Kidney & 275 & 21.5 & 31.1 & - & - \\
\hline HE-5 & (5 days) & (7 days) & (7 days) & (4 days) & (4 days) \\
\hline Skin & 15.6 & 15.6 & 4.6 & 5.0 & 10.0 \\
\hline Lung* & $<2.4$ & 21.3 & 12.0 & 12.0 & 16.5 \\
\hline Heart & 13.7 & 57.0 & 10.1 & 10.1 & 6.3 \\
\hline Kidney & 3.0 & 11.4 & 5.6 & 5.9 & $<5$ \\
\hline HE-6 & - (7 days) & & (4 days) & (4 days) & (6 days) \\
\hline Skin & 122 & - & 6.5 & 5 & 18.5 \\
\hline Lung & 422 & - & 380 & 75 & 143 \\
\hline Heart & 128 & - & 32 & 20 & 27 \\
\hline Kidney & 187 & - & $<5$ & $<5$ & $<5$ \\
\hline Body wall & 257 & - & 5.0 & 5.0 & 6.5 \\
\hline HE-7 & (4 days) & & (4 days) & & \\
\hline Skin & $138^{\circ}$ & - & 5.7 & - & - \\
\hline Liver & 138 & - & 9.4 & - & - \\
\hline Heart & 50 & - & 18 & - & - \\
\hline Kidney & 35 & - & 6.4 & - & - \\
\hline Body wall & 10 & - & 8 & - & - \\
\hline
\end{tabular}

Media were collected and assayed for alpha-2-macroglobulin and fibronectin. With the exception of the primary culture of HE-5 lung cells, all of the media assayed contained large amounts $(8-38 \mu \mathrm{g} / \mathrm{ml})$ of fibronectin, indicating that at each passage the cells were healthy and capable of protein synthesis and secretion. The figures in parentheses indicate the time the cells spent in the medium sampled. For primary cultures, this was the time after decantation of unadherent cells; for subsequent passages, this was the time after subculture. Values represent averages of duplicate cultures, each sample analyzed in duplicate. Except for the primary culture of HE-5 lung cells, all cultures were confluent at the times the media were harvested. At confluency, the cultures had the following properties: skin, monolayer of parallel, polar cells, contained 250-300 $\mu \mathrm{g}$ of protein per $20-\mathrm{cm}^{2}$ plate; lung, less parallel, in part oligolayers, contained $400-500 \mu \mathrm{g}$ protein per $20-\mathrm{cm}^{2}$ plate; heart, large, flat polygonal cells forming a loosely-packed monolayer, contained 250-300 $\mathrm{mg}$ protein per $20-\mathrm{cm}^{2}$ plate; kidney, either polar, fibroblastic cells or flat epithelioid cells, contained $250-400$ $\mu \mathrm{g}$ protein per $20-\mathrm{cm}^{2}$ plate; and body wall, large polar cells which formed a tight monolayer, contained $300-450 \mu \mathrm{g}$ protein per $20-\mathrm{cm}^{2}$ plate. Our observations on fibronectin content and distribution in these cultures will be reported elsewhere in a forthcoming paper.

* Cells grew out poorly in primary culture.

sage. The cultures were confluent, and substantial amounts of fibronectin $(8-38 \mu \mathrm{g} / \mathrm{ml})$ were present in growth media of all embryonic cell cultures at the times of sampling.

Effect of serum. Alpha-2-macroglobulin accumulated in media of MRC-5 fibroblasts regardless of whether serum was present or not (Table III).
Immunodiffusion. To corroborate the radioimmunoassay finding that skin fibroblasts synthesized and secreted less alpha-2-macroglobulin than lung fibroblasts, radio-labeled proteins appearing in the medium were analyzed after prolonged incubation with $\mathrm{L}-\left[{ }^{35} \mathrm{~S}\right]$ methionine. The medium was mixed with $1 / 20$ th volume of human plasma, and the globulins were precipitated from the mixture by $50 \%$ saturated ammonium sulfate. The plasma globulins served as carriers during the salt precipitation and subsequent immunodiffusion (Fig. 5). Radiolabel was detected by autoradiography in precipitin lines formed by reactions of both anti-fibronectin and anti-alpha-2-macroglobulin antisera against globulin fractions of media of both skin and lung fibroblasts. The skin fibroblasts appeared to make much more fibronectin than alpha-2-macroglobulin whereas the intensities of radiolabel in fibronectin and alpha-2macroglobulin immunoprecipitates of medium derived from lung fibroblasts were approximately equal. There was no evidence for incorporation of $L-\left[{ }^{35} S\right]$ methionine into plasma globulins other than fibronectin and alpha2-macroglobulin.

Immunoprecipitation. We were unable to detect human alpha-2-macroglobulin in fibroblast extracts by radioimmunoassay. We also could not visualize intracellular alpha-2-macroglobulin by indirect immunofluorescence of human fibroblast cultures fixed with formaldehyde and acetone. However, we were able to detect alpha-2-macroglobulin which had been endocytosed from calf serum-containing growth medium when the immunofluorescence staining was performed with anti-alpha-2-macroglobulin which was not previously adsorbed with calf serum.

A $1.6 \times 10^{5}$-dalton polypeptide co-migrating with alpha-2-macroglobulin was specifically precipitated by anti-alpha-2-macroglobulin from cell extracts of WI-38

TABLE III

Effect of Serum on Accumulation of Alpha-2-Macroglobulin in Media of Embryonic Lung Cells

\begin{tabular}{lccc}
\hline $\begin{array}{l}\text { Incubation } \\
\text { conditions }\end{array}$ & $\begin{array}{c}\text { Cell } \\
\text { protein }\end{array}$ & \multicolumn{2}{c}{ Alpha-2-macroglobulin } \\
\hline & $g$ & $n g /$ dish & $\begin{array}{c}\text { ng/mg } \text { cell } \\
\text { protein }\end{array}$ \\
& & & $530 \pm 230$ \\
Serum-free & $287 \pm 5$ & $153 \pm 67$ & $530 \pm 80$ \\
$1 \%$ serum & $371 \pm 16$ & $130 \pm 30$ & 350 \\
$10 \%$ serum & $441 \pm 23$ & $98 \pm 31$ & $220 \pm 60$ \\
\hline
\end{tabular}

MRC-5 cells were subcultured in $20-\mathrm{cm}^{2}$ petri dishes containing $5 \mathrm{ml}$ of growth medium. 3 days later, when the cells were semiconfluent, growth medium was removed and replaced with $2.2 \mathrm{ml}$ BMED containing $0.05 \%$ bovine serum albumin $10 \%$ PBS, $9 \%$ PBS and $1 \%$ fetal calf serum, or $10 \%$ fetal calf serum. After incubation for $24 \mathrm{~h}$, media were collected and assayed for alpha-2-macroglobulin. The numbers represent the mean \pm 1 SD of triplicate cultures. 


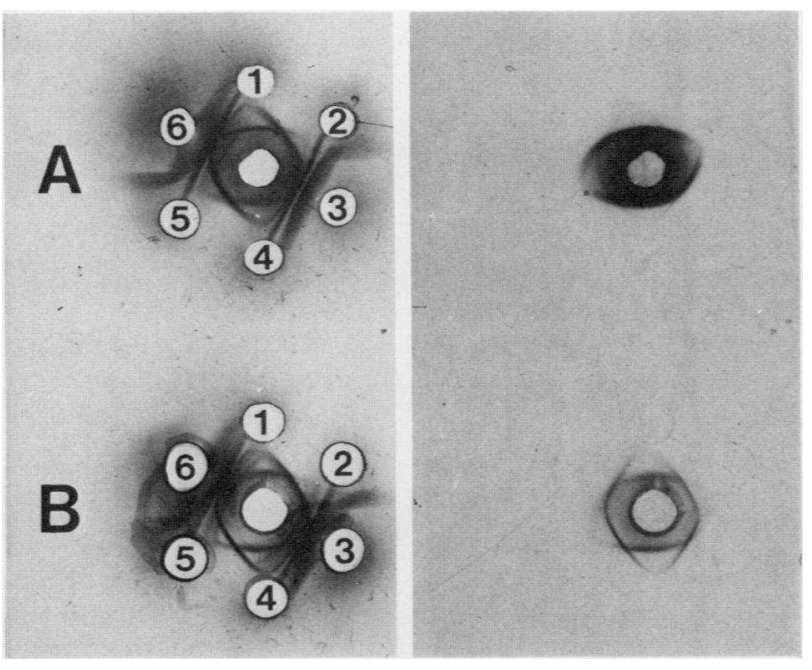

FIGURE 5 Immunodiffusion of proteins precipitated from a mixture of labeled medium and unlabeled plasma by $50 \%$ saturated ammonium sulfate. Cultures of human embryonic skin fibroblasts (A) or lung fibroblasts (B) were incubated with L- $\left.{ }^{35} \mathrm{~S}\right]$ methionine as described in Methods. After precipitation with $50 \%$ ammonium sulfate, proteins were dissolved in $1 / 1$ th of the volume of the original medium, and $10 \mu \mathrm{l}$ were placed in the center well. $10 \mu \mathrm{l}$ of antisera directed against fibronectin ( 1 and 4), alpha-2-macroglobulin (2 and 5), and whole human serum ( 3 and 6 ) were placed in the outer wells. The plate was washed, dried, stained for protein (left), and analyzed by autoradiography (right).

embryonic lung fibroblasts incubated for $4 \mathrm{~h}$ with $\mathrm{L}$ $\left[{ }^{35}\right.$ S]methionine (Fig. 6 , slot 4 ); this polypeptide was not immunoprecipitated from extracts of adult skin fibroblasts (Fig. 7, slot 4). Radiolabeled cellular fibronectin $\left(2.2 \times 10^{5}\right.$ daltons $)$ was immunoprecipitated

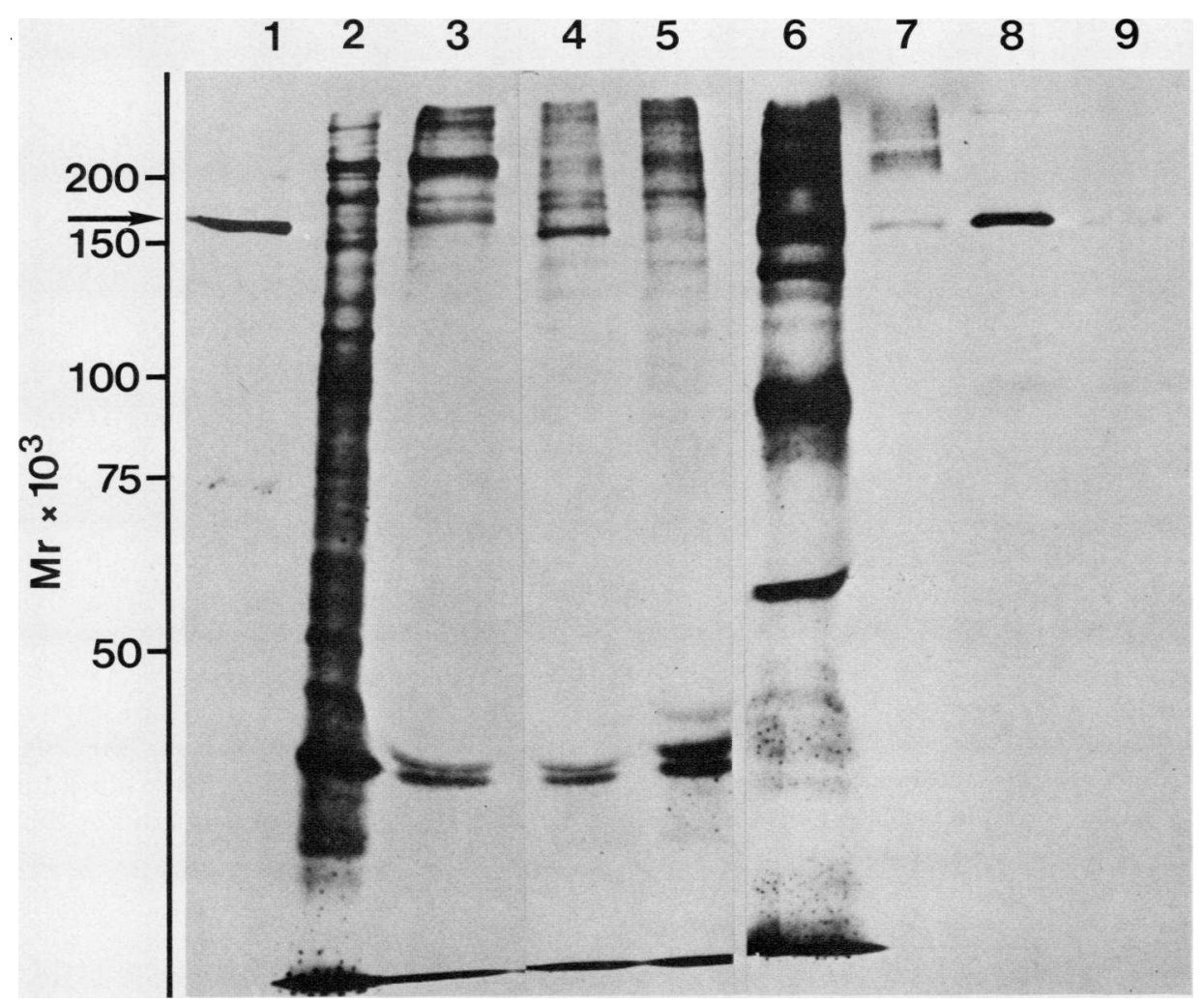

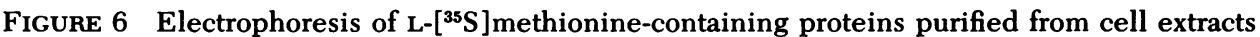
and medium of WI-38 embryonic lung fibroblasts by double antibody immunoprecipitation. Precipitates were dissolved in $4 \%$ sodium dodecyl sulfate, $10 \% 2$-mercaptoethanol and analyzed on a 3.5/6.0\% discontinuous polyacrylamide slab gel. The patterns shown are of nine slots of an autoradiogram of a 15-slot slab gel. Samples were: (1) ${ }^{125}$ I-labeled alpha-2-macroglobulin added to unconditioned medium and precipitated by anti-alpha-2-macroglobulin; (2) total cell extract; (3) cell extract precipitated by anti-fibronectin; (4) cell extract precipitated by anti-alpha-2-macroglobulin; (5) cell extract precipitated by normal rabbit serum; (6) total medium (precipitated by $5 \%$ trichloroacetic acid in the cold); (7) medium precipitated by anti-fibronectin; (8) medium precipitated by anti-alpha-2- macroglobulin; (9) medium precipitated by normal rabbit serum. An arrow points to the subunit of alpha-2-macroglobulin $\left(\mathrm{Mr}=1.6 \times 10^{5}\right.$ daltons). Molecular weight $\left(\mathrm{M}_{r}\right)$ markers are described in the text. 


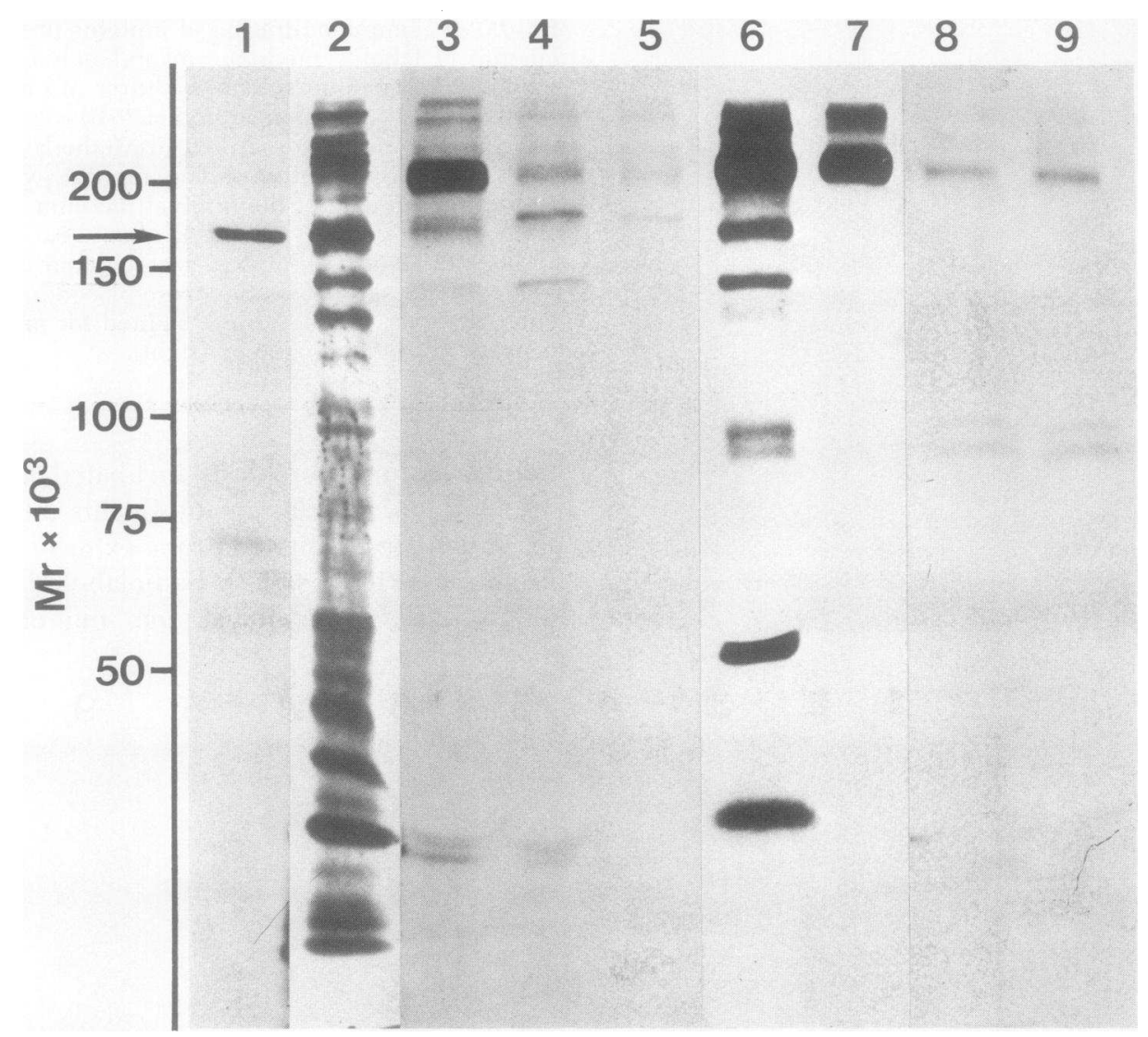

FIGURE 7 Electrophoresis of $\mathrm{L}_{-}\left[{ }^{35} \mathrm{~S}\right]$ methionine-containing proteins purified from cell extracts and medium of E. S. adult skin fibroblasts by double antibody immunoprecipitation. The analysis was performed as described in Fig. 6 .

from extracts of both cell strains using anti-fibronectin (Figs. 6 and 7, slot 3). Anti-alpha-2-macroglobulin immunoprecipitated a labeled $1.6 \times 10^{5}$ dalton polypeptide and trace polypeptides of very high molecular weight from medium of WI-38 cells (Fig. 6, slot 8). The alpha-2-macroglobulin immunoprecipitate of medium from skin fibroblast cultures labeled for the same time did not contain the $1.6 \times 10^{5}$-dalton polypeptide (Fig. 7 , slot 8). When a longer labeling time than $4 \mathrm{~h}$ was used, minute amounts of labeled $1.6 \times 10^{5}$-dalton polypeptide were found in the immunoprecipitate. The double-antibody immunoprecipitation analysis of medium gave two unexplained findings: (a) Small amounts of a $1.6 \times 10^{5}$-dalton polypeptide were found in immunoprecipitates of medium from WI-38 cells formed with anti-fibronectin or normal rabbit serum (Fig. 6, slots 7 and 9) and not just in the immunoprecipitate formed with anti-alpha-2-macroglobulin; and (b) Immunoprecipitates formed by anti-alpha-2-macroglobulin and normal rabbit serum but not by anti-fibronectin contained labeled polypeptides with molecular weights characteristic of collagen $\left(9.5 \times 10^{4}\right.$ and $1.1 \times 10^{5}$ for skin fibroblasts and $9.5 \times 10^{4}$ for lung fibroblasts).
Clot lysis. Inasmuch as a number of investigators have shown that embryonic lung fibroblasts, in contrast to adherent cells from other tissues, secreted substantial amounts of plasminogen activator (17-21), we tested the ability of our embryonic strains to lyse a clot formed from $10 \%$ human plasma. Lung fibroblasts completely lysed the clot in $18 \mathrm{~h}$, and heart fibroblasts partly lysed the clot. Clots remained intact over the other cells.

\section{DISCUSSION}

Previously, we reported several types of evidence which indicated that WI-38 human embryonic lung fibroblasts synthesized and secreted alpha-2-macroglobulin: $(a) \mathrm{L}-\left[{ }^{35} \mathrm{~S}\right]$ methionine was incorporated into a protein which was precipitated by anti-alpha-2macroglobulin antibody; (b) an intrinsically-labeled L$\left.{ }^{35} \mathrm{~S}\right]$ methionine-containing polypeptide of the expected size appeared in the medium; $(c)$ the concentration of alpha-2-macroglobulin (whether measured by Laurell's electroimmunoassay or by an activity assay which was based on the ability of alpha-2-macroglobulin to protect the esterase activity of trypsin from in- 
hibition by soybean trypsin inhibitor) increased with time in serum-free culture medium; and $(d)$ alpha-2macroglobulin did not appear in serum-free media of cultures incubated with puromycin, an antibiotic which blocks protein synthesis (2). In the present paper, we report two additional pieces of evidence which indicate that lung fibroblasts synthesize and secrete alpha-2-macroglobulin: $(e)$ the concentration of human alpha-2-macroglobulin, measured by a sensitive radioimmunoassay which did not detect bovine alphamacroglobulin, increased with time in calf serum-containing culture medium; and $(f)$ an intrinsically-labeled $1.6 \times 10^{5}$-dalton polypeptide, which comigrated exactly with the subunit of authentic alpha-2-macroglobulin, was specifically precipitated from medium and cell extracts by anti-alpha-2-macroglobulin. It should be noted that there were other polypeptides in the $1.6 \times 10^{5}$-dalton region of the gel which were not precipitated by anti-alpha-2-macroglobulin (Figs. 6 and 7 ). Thus, point $(b)$ described above is not a valid argument in favor of alpha-2-macroglobulin synthesis.

We were unable to detect a synthetic pool of alpha2 -macroglobulin by immunofluorescence or radioimmunoassay, although the immunofluorescence technique could detect bovine alpha-macroglobulin taken up from the growth medium. ${ }^{4}$ These observations suggest that alpha-2-macroglobulin is rapidly secreted into the medium. The intrinsically-labeled $1.6 \times 10^{5}$-dalton polypeptide which was specifically immunoprecipitated by anti-alpha-2-macroglobulin from cell extracts of WI-38 cells incubated for $4 \mathrm{~h}$ with $\left.\mathrm{L}-{ }^{35} \mathrm{~S}\right]$ methionine may have been secreted into the medium and then taken up inside the fibroblasts by endocytosis.

Four of the five strains of human embryonic lung cells studied secreted large amounts of alpha-2-macroglobulin into growth medium. The fifth strain (HE-5) grew poorly in primary culture and may have been composed of a restricted population of cells which were poor producers of alpha-2-macroglobulin. Established cultures of adherent cells from tissues other than lung accumulated much less alpha-2-macroglobulin in growth media. Two pieces of evidence suggest that these cultures did produce small amounts of alpha-2macroglobulin. First, although we were working at the lower limits of the sensitivity of the radioimmunoassay, in 45 out of 50 samples (Tables I and II), low concentrations of alpha-2-macroglobulin were detected in conditioned media. Second, skin fibroblasts incorporated small amounts of $\mathrm{L}-\left[{ }^{35} \mathrm{~S}\right]$ methionine into protein which was immunoprecipitated by anti-alpha-2-macroglobulin. Adherent cells from all tissues studied except lung secreted larger amounts of alpha-2-macroglobulin into medium while in primary culture than during sub-

\footnotetext{
${ }^{4}$ A separate report, now in preparation, will describe the endocytosis of alpha-2-macroglobulin in more detail.
}

sequent passages. We do not know why alpha-2-macroglobulin production decreased on subsequent passage of all except the lung cells. The cultures all grew well and secreted large amounts of fibronectin. The variations in accumulation of alpha-2-macroglobulin do not seem to be due to differing cell densities. Cell layers of cultures from body wall, which contained as much protein as cell layers of lung cells, produced little alpha2-macroglobulin. Cultures of heart cells, which accumulated more alpha-2-macroglobulin than cultures of kidney and skin cells in 7 of 10 comparisons (Table II), contained the same amount of cellular protein at confluency as cultures of kidney and skin cells. Finally, alpha-2-macroglobulin began accumulating in the media of lung cells shortly after subculture (Fig. 4).

In experiments similar to those shown in Fig. 5, Williams et al (22) found that tissue slices from a variety of mouse organs incorporated labeled amino acids into protein precipitated by anti-alpha-2-macroglobulin. These authors did not think their findings were conclusive evidence for alpha-2-macroglobulin synthesis because of the possibility that other proteins were labeled and bound to unlabeled alpha-2-macroglobulin. Gitlin and Biasucci (23) detected alpha-2-macroglobulin in serum of a 9.5-wk-old human embryo and found that cultures of blood and liver of 4-9-wk-old embryos incorporated amino acids into protein precipitated by anti-human alpha-2-macroglobulin. Alpha-2macroglobulin has been detected on the surface of human mononuclear blood cells (24); preliminary experiments indicate that these cells incorporate amino acids into protein precipitated by anti-alpha-2-macroglobulin (25). Our recent experiments indicate that cells of the monocyte-macrophage lineage account for most of the alpha-2-macroglobulin synthesized by peripheral blood cells (26). Becker and Harpel (27) found variable, but sometimes intense, alpha-2-macroglobulin immunofluorescence of human hepatocytes studied in fresh-frozen tissue sections; fibrocytes in vascular adventitia were not immunofluorescent. Finally, Nachman and Harpel identified considerable amounts of alpha-2-macroglobulin in platelet extracts (28). Thus, a variety of cell types, including fibroblasts, hepatocytes, monocytic blood cells, and megakaryocytes, may all synthesize alpha-2-macroglobulin.

The observation that strains of cultured adherent lung cells produce more alpha-2-macroglobulin than other adherent cells seems important for two reasons. First, our adherent lung cells, as with lung fibroblasts studied by others (17-21), secreted large amounts of plasminogen activator. The molecular weight of plasminogen activator is 3.9 to $5.0 \times 10^{4}(29,30)$, and the molecular weight of alpha-2-macroglobulin is approximately $7.2 \times 10^{5}(1)$. Coordinated release of a small protease and a large, more slowly diffusing, protease inhibitor may explain the following paradox-Lung 
fibroblasts, in serum-containing medium which contains several hundred microgram/milliliter of heterologous alpha-2-macroglobulin, readily lyse fibrin but maintain plasmin-sensitive $(31,32)$, surface-associated fibronectin molecules. The simultaneous secretion of a protease and a protease inhibitor may help in controlling the amounts of active protease in the microenvironment of the cell and allow both spatial and temporal differences of protease activity to occur. Second, secretion of alpha-2-macroglobulin by lung fibroblasts is clearly of relevance to the physiological and pathophysiological roles of proteases and protease inhibitors in the lung. Lung tissues are presumably exposed to many different proteases, whether inhaled, intrinsic, or blood-borne. The experimental models of emphysema induced by intratracheal administration of papain, collagenase, and elastase $(33,34)$ and the association of congenital alpha-1-antitrypsin deficiency with emphysema (35) suggest that unbalanced protease activity damages lung tissue. Conversely, hyaline membrane disease in premature infants has been associated with low fibrinolytic activity (36). Nagy et al. analyzed lysates of several human tissues and found that only lung tissue contained large amounts of plasminogen activator (37). Alpha-2-macroglobulin inhibits a very wide spectrum of neutral proteases, including bacterial proteases, plant proteases, elastase, collagenase, and plasmin (1). Alpha-2-macroglobulin secreted locally in the lung may modulate the physiological action of intrinsic proteases and provide a baseline defense against minor proteolytic insults. The much larger pool of circulating protease inhibitors presumably is needed when the major proteolytic systems involved in blood coagulation and inflammation are activated.

\section{ACKNOWLEDGMENTS}

We thank Professor Pekka Halonen for providing us with fibroblasts from rheumatoid synovia and Ms. Pirjo Sarjakivi, Anja Virtanen, and Virpi Tiilikainen for their fine assistance.

This work was supported by grant 1R01 CA 17373-01 from the National Cancer Institute, National Institutes of Health, Bethesda, Maryland, and by a grant from the Sigrid Jusẻlius Foundation, Helsinki.

\section{REFERENCES}

1. Barrett, A. J., and P. M. Starkey. 1973. The interaction of $\alpha_{2}$-macroglobulin with proteinases. Characterization and specificity of the reaction, and a hypothesis concerning its molecular mechanism. Biochem. J. 133: 709724.

2. Mosher, D. F., and D. A. Wing. 1976. Synthesis and secretion of $\alpha_{2}$-macroglobulin by cultured human fibroblasts. J. Exp. Med. 143: 462-467.

3. Reich, E., D. Rifkin, and E. Shaw, editors. 1975. Proteases and Biological Control. Cold Spring Harbor Laboratory, Cold Spring Harbor, N. Y. 1021 pp.

4. Junod, A. F. and R. de Haller, editors. 1975. Lung Metabolism: Proteolysis and Antiproteolysis, Biochem- ical Pharmacology, Handling of Bioactive Substances. Academic Press Inc., New York.

5. Keski-Oja, J., D. F. Mosher, and A. Vaheri. 1976. Cross-linking of a major fibroblast surface-associated glycoprotein (fibronectin) catalyzed by blood coagulation factor XIII. Cell. 9: 29-35.

6. Mosher, D. F. 1975. Cross-linking of cold-insoluble globulin by fibrin-stabilizing factor. J. Biol. Chem. 250: 6614-6621.

7. Roberts, R. C., W. A. Reisen, and P. K. Hall. 1974. On the quaternary structure of human serum $\alpha_{2}$-macroglobulin. In Proteinase Inhibitors. H. Fütz, H. Tschesche, L. J. Greene, and E. Truschert, editors. Springer-Verlag New York Inc. 63-71.

8. Laurell, C. B. 1972. Electroimmunoassay. Scand. J. Lab. Clin. Invest. 29: 21-38.

9. Krohn, K., L. Sherman, and M. Welch. 1972. Studies of radioiodinated fibrinogen. I. Physicochemical properties of the $\mathrm{ICl}$, chloramine-T, and electrolytic reaction products. Biochim. Biophys. Acta. 285: 404-413.

10. Lowry, O. H., N. J. Rosebrough, A. L. Farr, and R. J. Randall. 1951. Protein measurement with the Folin phenol reagent. J. Biol. Chem. 193: 265-275.

11. Russell, W. C., C. Newman, and D. H. Williamson. 1975. A simple cytochemical technique for demonstration of DNA in cells infected with mycoplasmas and viruses. Nature (Lond.). 253: 461-462.

12. Hayflick, L., and P. S. Moorhead. 1961. The serial cultivation of human diploid cell strains. Exp. Cell Res. 25: 585-621.

13. Jacobs, P. J., C. M. Jones, and J. P. Baille. 1970. Characteristics of a human diploid cell designated MRC-5. Nature (Lond.). 227: 168-170.

14. Ames, G. F-L. 1974. Resolution of bacterial proteins by polyacrylamide gel electrophoresis on slabs. Membrane, soluble and periplasmic fractions. J. Biol. Chem. 249: $634-644$.

15. Laskey, R. A., and A. D. Mills. 1975. Quantitative film detection of ${ }^{3} \mathrm{H}$ and ${ }^{14} \mathrm{C}$ in polyacrylamide gels by fluorography. Eur. J. Biochem. 56: 335-341.

16. Rice, R. H., and G. E. Means. 1971. Radioactive labeling of proteins in vitro. J. Biol. Chem. 246: 831-832.

17. Bernik, M. B., and H. C. Kwaan. 1969. Plasminogen activator activity in cultures from human tissues. An immunological and histochemical study. J. Clin. Invest. 48: $1740-1753$.

18. Rifkin, D. B., J. N. Loeb, G. Moore, and E. Reich. 1974. Properties of plasminogen activators formed by neoplastic human cell cultures. J. Exp. Med. 139: 1317-1328.

19. Mott, D. M., P. H. Fabisch, B. P. Sani, and S. Sorof. 1974. Lack of correlation between fibrinolysis and the transformed state of cultured mammalian cells. Biochem. Biophys. Res. Commun. 61: 621-627.

20. Laug, W. E., P. A. Jones, and W. F. Benedict. 1975. Relationship between fibrinolysis of cultured cells and malignancy. J. Natl. Cancer Inst. 54: 173-179.

21. Pearlstein, E., R. O. Hynes, L. M. Franks, and V. J. Hemmings. 1976. Surface proteins and fibrinolytic activity of cultured mammalian cells. Cancer Res. 36: 14751480.

22. Williams, C. A., Jr., R. Asofsky, and G. J. Thorbecke. 1963. Plasma protein formation in vitro by tissues from mice infected with staphylococci. J. Exp. Med. 118: 315326.

23. Gitlin, D., and A. Biasucci. 1969. Development of $\gamma \mathrm{G}, \gamma \mathrm{A}, \gamma \mathrm{M}, \beta 1 \mathrm{C} / \beta 1 \mathrm{~A}, \mathrm{C}^{\prime} \mathbf{l}$ esterase inhibitor, ceruloplasmin, transferrin, hemopexin, haptoglobin, fibrinogen, plasminogen, $\alpha_{1}$-antitrypsin, orosomucoid, $\beta$-lipoprotein, 
$\alpha_{2}$-macroglobulin, and prealbumin in the human conceptus. J. Clin. Invest. 48: 1433-1446.

24. McCormick, J. N., D. Nelson, A. M. Tunstall, and K. James. 1973. Association of $\alpha$-macroglobulin with lymphoid cells. Nat. New Biol. 246: 78-81.

25. Tunstall, A. M., and K. James. 1974. Preliminary studies on the synthesis of $\alpha_{2}$-macroglobulin by human lymphocytes in vitro. Clin. Exp. Immunol. 17: 697-701.

26. Hovi, T., D. F. Mosher, and A. Vaheri. 1977. Cultured human monocytes synthesize and secrete $\alpha_{2}$-macroglobulin. J. Exp. Med. 145: 1580-1589.

27. Becker, C. G., and P. C. Harpel. 1976. Alpha $a_{2}$-macroglobulin on human vascular endothelium. J. Exp. Med. 144: $1-9$.

28. Nachman, R. L., and P. C. Harpel. 1976. Platelet $\alpha_{2}$ macroglobulin and $\alpha_{1}$-antitrypsin. J. Biol. Chem. 251: 4514-4521.

29. Unkeless, J., K. Danø, G. M. Kellerman, and E. Reich. 1974. Fibrinolysis associated with oncogenic transformation. Partial purification and characterization of the cell factor, a plasminogen activator. J. Biol. Chem. 249: 42954305.

30. Christman, J. K., and G. Acs. 1974. Purification and characterization of a cellular fibrinolytic factor associated with oncogenic transformation: The plasminogen activator from SV-40-transformed hamster cells. Biochim. Biophys. Acta. 340: 339-347.
31. Blumberg, P. M., and P. W. Robbins. 1975. Effect of proteases on activation of resting chick embryo fibroblasts and on cell surface proteins. Cell. 6: 137-147.

32. Hynes, R. O., J. A. Wyke, J. M. Bye, K. C. Humphryes, and E. S. Pearlstein. 1975. Are proteases involved in altering cell surface proteins during viral transformation? In Proteases and Biological Control. E. Reich, D. Rifkin, and E. Shaw, editors. Cold Spring Harbor Laboratory, Cold Spring Harbor, N. Y. 2: 931-944.

33. Marco, V., D. R. Meranze, M. Hoshida, and P. Kimbel. 1972. Papain-induced experimental emphysema in the dog. J. Appl. Physiol. 33: 293-299.

34. Johanson, W. G., and A. K. Pierce. 1972. Effects of elastase, collagenase and papain on structure and function of rat lungs in vitro. J. Clin. Invest. 51: 288-293.

35. Eriksson, S. 1964. Pulmonary emphysema and alphaantitrypsin deficiency. Acta Med. Scand. 175: 197-205.

36. Ambrus, C. M., T. S. Choi, D. H. Weintraub, B. Eisenberg, H. P. Staub, N. G. Courey, R. J. Foote, D. Goplernd, R. V. Moesch, M. Ray, I. D. J. Bross, O. S. Jung, I. B. Mink, and J. L. Ambrus. 1975. Studies on the prevention of respiratory distress syndrome of infants due to hyaline membrane disease with plasminogen. Sem. Thromb. Hemostasis 2: 42-51.

37. Nagy, B., J. Ban, and B. Brdar. 1977. Fibrinolysis associated with human neoplasia: Production of plasminogen activator by human tumours. Int. J. Cancer. 19: 614-620. 